\title{
Water conservation and water recycling program implementations at University of Kashan
}

\author{
Majid Monemzadeh ${ }^{*}$ \\ Vice-Chancellor for Research of Kashan University
}

\begin{abstract}
University of Kashan was founded in 1974 and is the oldest institution of higher education in Kashan. At the time of its foundation, only undergraduate courses in Physics and Mathematics were offered. The current activities of the university are classified into four sections of education, research, development, and side activities. The university is located on a 530 hectares campus, 15 kilometres outside of the town with several affiliated centres located near or at city of Kashan, Ghamsar, Niasar and Tehran. Presently, the university has nearly 300 staff and university lecturers and it has about 8200 students, studying in over 180 courses. Kashan University has awarded and certificated one of the most active universities in the Green Management. Some of the activities of Green Management of Kashan University includes, CCHP Plant, Sewerage Disposal, and Water saving policy, natural ventilation, using efficient applicants. The current paper studies some of the main activities of University of Kashan in Water conservation and water recycling programs.
\end{abstract}

\section{Introduction}

Kashan is an ancient historical city with an outstanding record in many different aspects of Persian Civilization, culture and development dating back to 7000 years ago. Archaeological discoveries in the Sialk Hillocks which lie $4 \mathrm{~km}$ west of Kashan reveal that this region was one of the primary centres of civilization in pre-historic ages. Hence, Kashan dates back to the Elamite period of Iran. The Sialk ziggurat still stands today in the suburbs of Kashan after 7,000 years [1].

Great many scholars, scientists, philosophers and thinkers from this city have contributed to the development of its Islamic history. There are a large number of historical sites in Kashan which includes some of the best and most attractive classical architectures in historical housing of Iran.

Kashan ( $\left.33^{\circ} 58^{\prime} 59^{\prime \prime} \mathrm{N} / 51^{\circ} 25^{\prime} 56^{\prime \prime} \mathrm{E}\right)$ climate is classified as BWhsa by the Köppen-Geiger system, with hot and dry climate and virtually no rainfall during the year [2], where $\mathrm{B}$ is dryness; $\mathrm{W}$ is the intensity of dryness where the average annual rainfall (13.5) is lower than the average annual temperature in ${ }^{\circ} \mathrm{C}$ (19.7). $\mathrm{h}$ shows that the average annual temperature is above 18 ${ }^{\circ} \mathrm{C}$, s is the sign of rain in the cold seasons or the winter and a show that the temperature in the warmest month of the year is above $22{ }^{\circ} \mathrm{C}$ [1]. According to DeMarttone climatic classification which is based on the dryness coefficient and considers two factors of temperature and rainfall, the climate of Kashan is dry with dryness coefficient of 4.5 .

University of Kashan was founded at first as an institution of higher education in 1973. It began its activities in October 1974 by 200 students of mathematics and physics. In 1989 more academic fields were added and the institution continued its activities as Kashan Teacher-Training University under the supervision of the Ministry of Science. In 1994, by offering engineering disciplines, this university was acknowledged as a main university by the Ministry of Science. In 1995 College of Architecture and Arts was added to the university with an emphasis on the local needs, art and industries of the region. Faculty of Chemistry, as the 5th college after Science, Humanities, Engineering, Architecture and Arts, was founded in 2008. Currently, University of Kashan, within the boundary of 530 hectares and with 80000 square meters of infrastructure (building), in addition to educational campuses, sports facilities, dormitory complexes, restaurant complex, amphitheatres, green spaces, mosque, study halls and health-care centre provides leisure, services and comforts to the students. Besides the five mentioned colleges, there are three active research institutes including Nano Technology, Natural Essential Oils, and Energy and also three Research Centres including Kashan studies, Carpet, and Astronomy that contribute to the fact that University of Kashan in recent years has been among the top ten universities in Iran. Accommodating more than 7500 students in 50 disciplines of undergraduate, graduate and postgraduate levels and having about 300 full-time faculty members.

\section{Water crisis in Iran and city of Kashan}

Iran is located at the southwest of Asia and in the northern hemisphere desert belts and this situation has caused a large area of Iran to be affected by dry and 
semi-arid climate, facing Iran with water shortage. Iran faced a growing water crisis [3]. Especially, with the annual rain fall of $50 \mathrm{~mm}$ in the central plains of Lut, living conditions in the marginal areas of desert is arduous and intolerable. The southern and central regions of Iran including Kashan are having a severe shortage of rain and, day by day, water resources, especially groundwater, are reducing. The average annual rainfall in Kashan is $116 \mathrm{~mm}$ and evaporation are high too; on the other hand, about 25 million hectares of Iranian lands are classified as pasture lands of which region of Kashan is a part. Therefore, soil salinity, dry climate of Kashan, and immethodical deep and semideep well drilling has put sources of fresh water subject to salinization.

\section{Water supply at University of Kashan}

University of Kashan absorbs water from the wells drilled at the university. In recent years, however, due to the drop in underground water levels, the depth of the wells has grown. Currently, it takes at least 250 meters to reach water.

It is estimated that, in the coming years, deeper wells should be drilled to receive water.

Due to the shortage of water it faces, University of Kashan is implementing and planning various strategies to store, recycle, and treat water.

\section{University of Kashan's activities about water}

- Conferences and workshop for professors, students, and staff on optimal consumption and water saving

- Drop irrigation for an area of over 2,000 meters at University's campus

- Cultivation of plants appropriate to the climate, plants that require lower amount of water

- Using optimal showers in dormitories. Major water consumption at University are related to bathrooms.

- Construction of $120 \mathrm{~m} 3$ wastewater treatment plant applicable for 200 people by charity investments

- Purchasing new washing machines with an energy labels for installation in dormitories. (These replacements cause water and energy savings)

- Construction of artificial turf football field

- Water storage at the Essential Oils research centre, University of Kashan

\subsection{Example of courses/modules related to water (University of Kashan, Kashan)}

Table 1 Courses/modules related to water

\begin{tabular}{|c|c|}
\hline \multicolumn{2}{|c|}{ Courses/modules related to water } \\
\hline courses/modules & $\begin{array}{c}\text { Faculty/ } \\
\text { Department }\end{array}$ \\
\hline $\begin{array}{l}\text { - Wastewater Treatment and Recycling } \\
\text { - Water Resources Management } \\
\text { - Wastewater treatment } \\
\text { - Economic and social issues of } \\
\text { watersheds } \\
\text { - water resource management } \\
\text { - water quality } \\
\text { - Engineering structures for water and } \\
\text { soil protection } \\
\text { - Management and exploitation of } \\
\text { unconventional waters } \\
\text { - Simulation in Watershed }\end{array}$ & $\begin{array}{c}\text { Natural } \\
\text { Resource } \\
\text { Faculty }\end{array}$ \\
\hline $\begin{array}{l}\text { - Water treatment and sewage } \\
\text { treatment } \\
\text { - Water and wastewater treatment of } \\
\text { food industry }\end{array}$ & $\begin{array}{l}\text { The } \\
\text { Department of } \\
\text { Chemistry } \\
\text { Engineering }\end{array}$ \\
\hline $\begin{array}{l}\text { - Water treatment and } \\
\text { treatment }\end{array}$ & $\begin{array}{l}\text { The } \\
\text { Department of } \\
\text { Biology and } \\
\text { Civil } \\
\text { Engineering }\end{array}$ \\
\hline
\end{tabular}

\subsection{Water recycling program implementation}

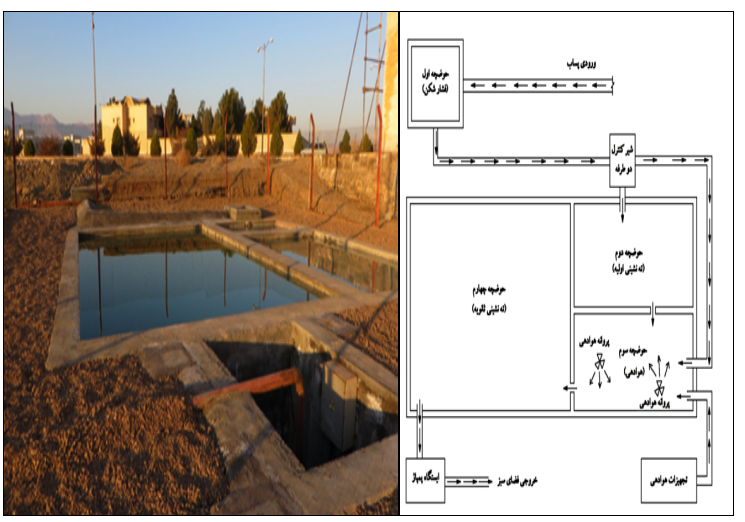

Fig. 1. Utilization of the first water recycling plant in Iranian Universities

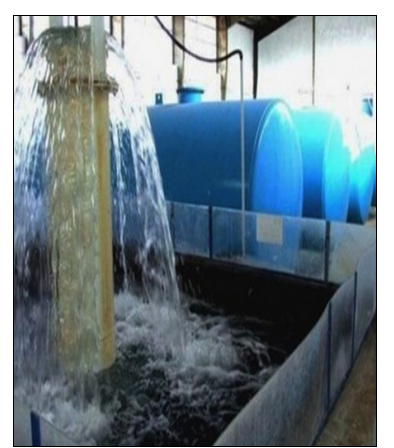

Fig. 2. Utilization of the first wastewater treatment plant in Iranian Universities 


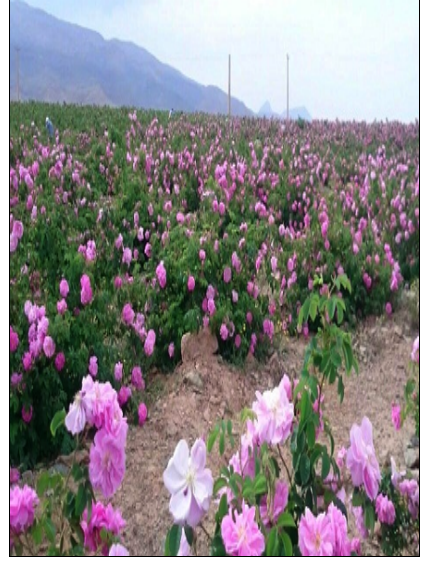

Fig. 3. 2 hectares of Rose Mohammadi (rose flower) irrigated with refined waste water and sewerage disposal at Kashan University

\section{Conclusion in Our University}

In, a reused wastewater treatment system was designed and implemented that was able to recover gray wastewater with a flow rate of 30 cubic meters per day. The purpose of this study was to investigate the effect of aeration system on the removal of pollutants from wastewater for use in agricultural applications. In the first step, the study was conducted with the establishment of a research pilot, quality raw sewage and refined wastewater of a sports complex. Then, according to the results obtained from the wastewater volume and the severity of the input of wastewater pollution, design of the main purification units was carried out. The results showed that using this method, the amount of oxygen required for chemical and biochemical processes, as well as the total soluble solids, have reached a standard for use in the field of green space. The treated wastewater was used for agricultural purposes and water supply needed for the new farm of 2 hectares of rose Mohammadi (Rose Flower).

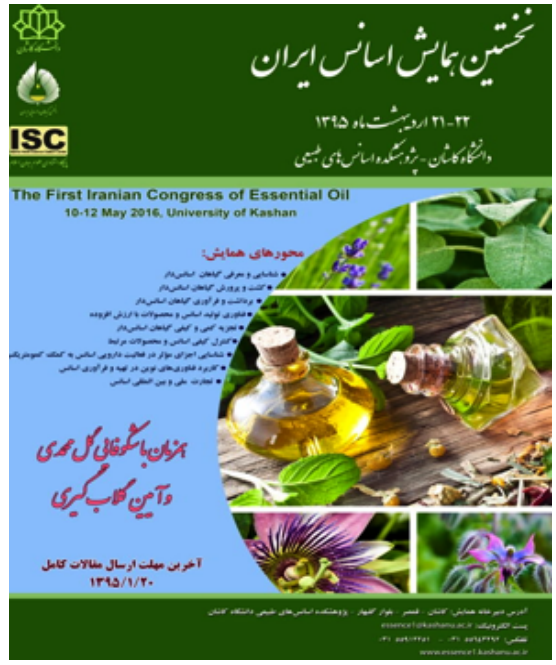

Fig. 4. Especial flowers and green space of Kashan

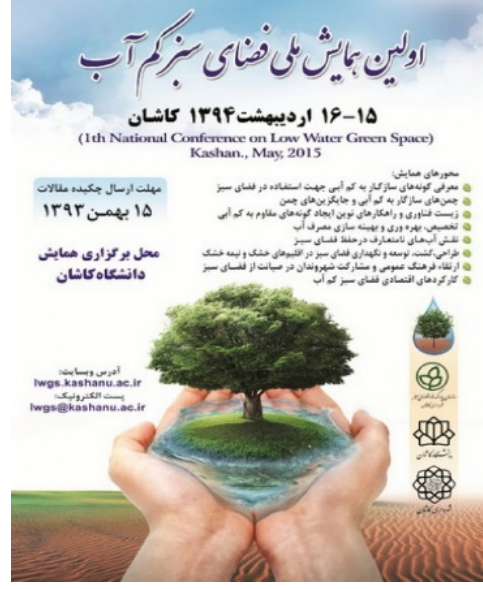

Fig. 5. Conference about green space with optimum water usage

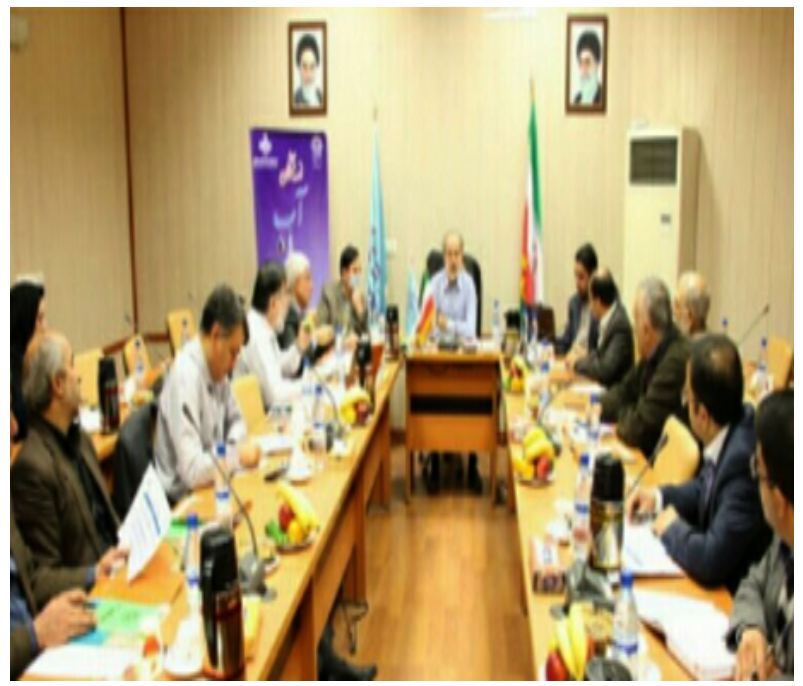

Fig. 6. Workshop about water management in Kashan University by Professor Reza Mansouri

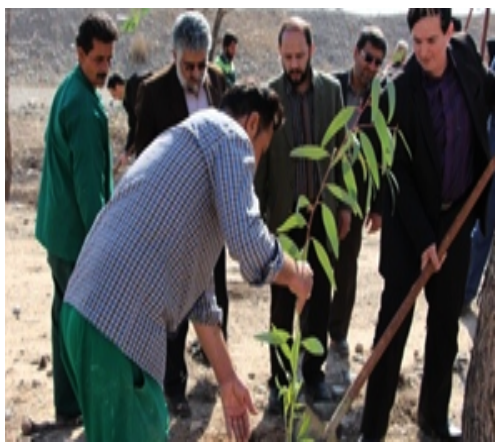

Fig. 7. Program for planting trees by university staff and the president of the university

These are Examples of Events Related to Environment and Sustainability (University of Kashan, Iran) 


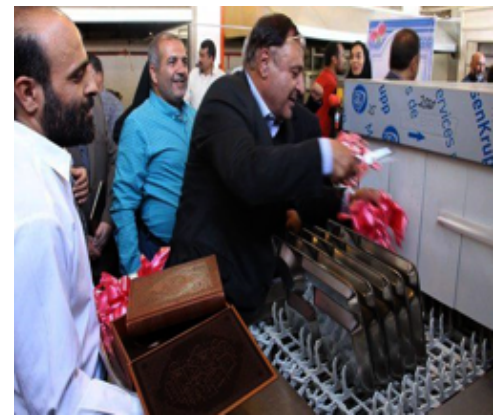

Fig. 8. Installation of automatic dish washing machine in the Restaurants of University of Kashan

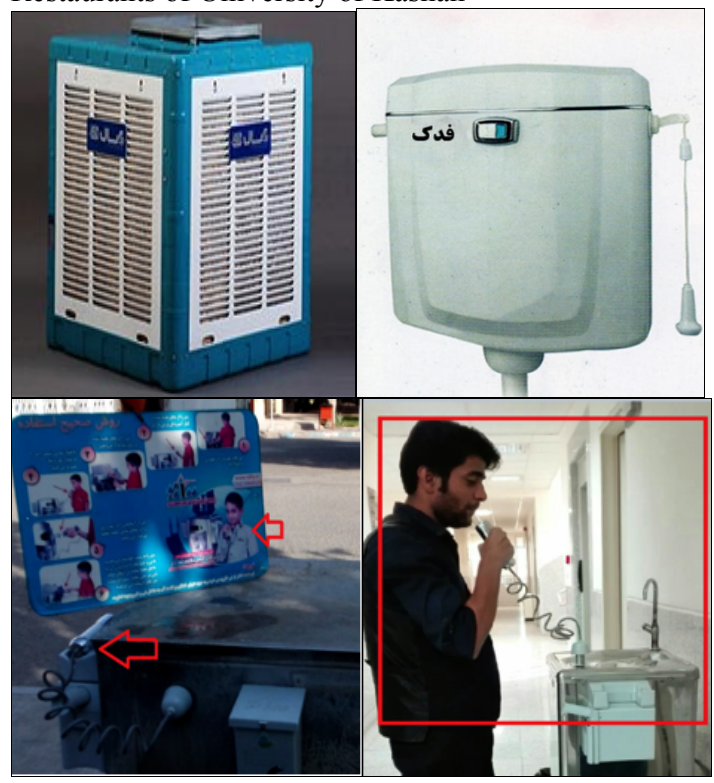

Fig. 9. Using the campus drinking water with straw in Kashan University to reduce plastic glass and saving water

Example of the use of water efficient appliances (toilet flush) in Kashan University, Kashan:

- Optimizing all coolers and chillers to saving waste water.

- University of Kashan has used the innovation in reducing use of plastic glass and saving water policy, with this Campus

Drinking Water, there is more than $80 \%$ saving in Water and reducing in plastic.

\section{References}

1. Jomehpour, M., Qanat irrigation systems as important and ingenious agricultural heritage: case study of the qanats of Kashan, Iran, International Journal of Environmental Studies, 66(3), 297-315. (2009)

2. Korsavi, S. S., Zomorodian, Z. S., \& Tahsildoost, $\mathrm{M}$, Energy and economic performance of rooftop $P V$ panels in the hot and dry climate of Iran. Journal of Cleaner Production, 174, 1204-1214. (2018)

3. Michel, D, 9 Iran's Impending Water Crisis. Water, Security and US Foreign Policy, 168 (2017) 